\title{
Conditioned taste aversion induced by 2,4,5-trichlorophenoxyacetic acid: Dose-response and preexposure effects
}

\author{
PER-OLOW SJÖDÉN, TREVOR ARCHER, and NED CARTER \\ Neurophysiological Laboratory, Ulleräker Hospital, Uppsala University, S-750 17, Uppsala, Sweden
}

\begin{abstract}
Taste aversion to a $.1 \%$ saccharin (sacc) solution was induced in rats by pairing sacc consumption with an oral dose of 2,4,5-trichlorophenoxyacetic acid (2,4,5-T). In Experiment 1, a critical dose range for producing taste aversion with 2,4,5-T was found from between 15 and $40 \mathrm{mg} / \mathrm{kg}$ and upwards. In Experiment 2, preconditioning exposure of the animals to sacc and/or the 2,4,5-T injection reduced the strength of the aversion. The possible risk of producing alterations of food preferences in wildlife through a widespread use of $2,4,5-\mathrm{T}$ as a herbicide is discussed.
\end{abstract}

The phenoxy herbicides have been in general use as a means to control broad-leaved weeds and brush for approximately 30 years. One of the most widely used phenoxy herbicides is 2,4,5-trichlorophenoxyacetic acid $(2,4,5-\mathrm{T})$, which has become important in silvicultural as well as in agricultural use. This substance has been subjected to investigations from a variety of viewpoints. Thus, teratogenic and toxicological properties have been studied (Courtney \& Moore, 1971; Khera \& McKinley, 1972; Neubert \& Dillman, 1972). Also, long-term behavioral effects in rat offspring of mothers given a single oral dose of 2,4,5-T during pregnancy (Sjödén \& Söderberg, 1972, 1975) have been reported. Acute effects of $2,4,5-\mathrm{T}$ on a variety of physiological parameters in adult animals have also been found (Florsheim \& Velcoff, 1962; Sjödén, Archer, \& Söderberg, 1977).

We have recently demonstrated a long-standing aversion to saccharin (sacc) in rats, induced by a single pairing of an oral injection of 2,4,5-T with sacc consumption (Sjödén \& Archer, 1977). The aversion persisted in spite of three extinction tests, a 9-day period of free water-drinking, and a 24-h period of forced sacc intake. Thus, it seems as if 2,4,5-T possesses marked taste-aversion-inducing properties, at least in doses of $100 \mathrm{mg} / \mathrm{kg}$ via the oral route. The data raise the possibility that a widespread use of 2,4,5-T as an herbicide may cause taste aversions with accompanying alterations of food preferences in wildlife. However, the question of doseresponse relations must be clarified before a full appreciation of long-term ecological effects will be possible. In the present study, therefore, oral doses of $2,4,5-\mathrm{T}$ in the range between 5 and $100 \mathrm{mg} / \mathrm{kg}$ will

This work was supported by Grant B75-14X-3889-03B from the Swedish Medical Research Council and by Contract 7-4/74 from the National Swedish Environment Protection Board. be employed as a toxic agent to induce sacc aversion in rats.

It has been repeatedly shown that exposure of animals to either the toxic agent (e.g., Cappell \& LeBlanc, 1975) or the taste substance (e.g., Domjan, 1972) prior to taste-aversion conditioning significantly reduces or abolishes the possibility of producing taste aversion involving the particular substances. This piece of information has a definite bearing on the question of long-term ecological effects of widespread use of $2,4,5-\mathrm{T}$, since an alteration of food preferences in wildlife presupposes a taste-aversion effect of 2,4,5-T with familiar food substances. The present experiment will include an attempt to study the effects of preexposure to the toxic and taste substances, by administering additional sacc- $2,4,5-\mathrm{T}$ pairings after a number of preference tests.

\section{EXPERIMENT 1}

\section{Method}

Subjects and Apparatus. The subjects were 40 naive male Wistar rats (Rattus Norvegicus, K. E. Møllegaard, Denmark) with a mean weight of $305 \mathrm{~g}$ at the beginning of the experiment. They were individually housed in acrylic cages $(16.5 \times 22.5 \times 13.5 \mathrm{~cm})$ and were allowed an acclimatization period of 2 weeks prior to the experiment. Food (a commercial-type pelleted diet, lab chow R3, Astra-Ewos, Södertälje, Sweden) was available ad lib in the roof of the cages. Water and/or saccharin was available in Techniplast (Italy) $250-\mathrm{ml}$ plastic bottles, with a steel ball inside the stainless steel drinking spout to minimize leakage yet allow unimpeded fluid access. The rats were divided in six groups $(n=6$ or 7$)$, matched for body weight. Throughout the experiment, they were placed on a 12-h-on/12-h-off lighting schedule (lights on at $0600 \mathrm{~h}$ ) in a room thermostatically maintained between $21^{\circ}$ and $24^{\circ}$.

Procedure. The entire experiment covered 39 days. All injections and tests were interspersed with 3-day periods of $10 \mathrm{~min} /$ day of water-drinking.

Prior to Day 1, the rats had been deprived of water for $24 \mathrm{~h}$. On Days 1-6, the rats were given access to water for $1 \mathrm{~h}, 30,15,15$, 10 , and $10 \mathrm{~min}$, respectively. This was intended to familiarize the animals with having access to drinking fluid for $10 \mathrm{~min} /$ day 
Table 1

Schedule of Experimental Treatments and Saccharin (Sacc) Preference Tests of Experiment 1

\begin{tabular}{|c|c|c|c|c|c|c|}
\hline Group & Day 7 & Days $11,15,19$ & Day 23 & Day 27 & Day 31 & Days 35,39 \\
\hline $100 \mathrm{mg} / \mathrm{kg}$ & Sacc-2, 4, 5-T & Tests $1,2,3$ & Test 4 & Test 5 & Sacc-2, 4, 5-T & Tests 6,7 \\
\hline $40 \mathrm{mg} / \mathrm{kg}$ & Sacc- $2,4,5-T$ & Tests $1,2,3$ & Test 4 & Test 5 & Sacc- $2,4,5-\mathrm{T}$ & Tests 6,7 \\
\hline $15 \mathrm{mg} / \mathrm{kg}$ & Sacc-2, 4, 5-T & Tests $1,2,3$ & Sacc-2, 4, 5-T & Sacc- $2,4,5-\mathrm{T}$ & Sacc-2, 4, 5-T & Tests 6,7 \\
\hline $5 \mathrm{mg} / \mathrm{kg}$ & Sacc- $2,4,5-T$ & Tests $1,2,3$ & Sacc- $2,4,5-\mathrm{T}$ & Sacc-2, 4, 5-T & Sacc- $2,4,5-\mathrm{T}$ & Tests 6,7 \\
\hline Oil Control & Sacc-oil & Tests $1,2,3$ & Sacc-oil & Sacc-oil & Sacc-oil & Tests 6,7 \\
\hline Uninjected & Sacc- & Tests $1,2,3$ & Test 4 & Test 5 & Sacc & Tests 6,7 \\
\hline
\end{tabular}

only (from 1000 to $1010 \mathrm{~h}$ ). During this period, the rats were given two bottles, one empty and one filled with water. The position of the water bottle was alternated in a RRLRLL sequence. Water intake was measured by weighing the bottles to the nearest $.1 \mathrm{~g}$ during Days 4-6. On Day 7, all animals were given $10 \mathrm{~min}$ access to a $.1 \%$ sacc solution in two identical bottles and subsequently injected (via stomach intubation) according to the following pattern (Table 1): (1) the $100-\mathrm{mg} / \mathrm{kg}$ group $(\mathrm{n}=7)$, given a single oral dose of $100 \mathrm{mg} / \mathrm{kg}$ of $2,4,5-\mathrm{T}$ (contaminated by less than $1 \mathrm{ppm} 2,3,7,8$-tetrachlorodibenzo-p-dioxin) suspended in $.3 \mathrm{ml}$ corn oil, (2) the $40-\mathrm{mg} / \mathrm{kg}$ group $(\mathrm{n}=7),(3)$ the $15-\mathrm{mg} / \mathrm{kg}$ group $(n=7),(4)$ the $5-\mathrm{mg} / \mathrm{kg}$ group $(\mathrm{n}=7),(5)$ the oil control $(\mathrm{n}=6)$, given $.3 \mathrm{ml}$ corn oil only, and $(6)$ the uninjected control $(n=6)$. All injections were carried out $1 \mathrm{~h}$ after the start of the drinking period.

Preference tests (T1-T3) were performed on Days 11, 15, and 19 , utilizing a two-bottle procedure (Grote \& Brown, 1971). One water and one sacc bottle were simultaneously inserted at $1000 \mathrm{~h}$ and left in position for $12 \mathrm{~h}$, and the position of the sacc bottle was alternated between tests. Intake of sacc $(.1 \%)$ and water was measured and sacc preference was expressed in terms of total fluid intake. On Days 23 and 27, the 100-mg, 40-mg, and uninjected control groups received additional preference tests (T4 and T5), the 15-mg and 5-mg groups received additional sacc-2,4,5-T pairings, and the oil-control group received sacc-oil pairings (Table 1). On Day 31, all groups were given the Day 7 treatment anew. Two additional preference tests (T6 and T7) were administered to all groups on Days 35 and 39.

\section{Results}

Analysis of variance (Kirk, 1968) showed no significant differences between the groups with regard to water intake during Days 4-6 and 8-10. Mean values of Day 7 sacc intake were: $100 \mathrm{mg}=16.1 \mathrm{~g}$, $40 \mathrm{mg}=13.8 \mathrm{~g}, 15 \mathrm{mg}=14.4 \mathrm{~g}, 5 \mathrm{mg}=14.3 \mathrm{~g}$, oil $=14.5 \mathrm{~g}$, and uninjected: $10.0 \mathrm{~g}$. These values were not significantly different.

Analysis of data from preference tests 1-3 revealed a Group by Tests interaction $(F=2.0, \mathrm{df}=10 / 68$, $\mathrm{p}<.05$ ) (Figure 1).

Subsequent testing of pairwise differences with the Tukey HSD test (Kirk, 1968, pp. 112-113) revealed that the 100 - and $40-\mathrm{mg} / \mathrm{kg}$ groups showed significantly lower sacc-preference values than the oil and uninjected groups for $\mathrm{T} 1$ and $\mathrm{T} 2$, and the $40-\mathrm{mg} / \mathrm{kg}$ group showed a lower value than the oil and uninjected groups for T3 $(p<.01)$. Also, all 2,4,5-Tinjected groups increased their sacc preference significantly from T1 to T3. Mean sacc-preference values at $\mathrm{T} 4$ and T5 were: $100 \mathrm{mg}=80.4 \%$ and $90.4 \%$, $40 \mathrm{mg}=72.5 \%$ and $84.8 \%$, and uninjected $=89.3 \%$ and $97.3 \%$. These values were not significantly dif- ferent. The final preference tests (T6 and T7) revealed no difference between the groups.

\section{EXPERIMENT 2}

Experiment 1 reveals a critical dose range for the oral route of administration between 15 and $40 \mathrm{mg} / \mathrm{kg}$ of 2,4,5-T in taste-aversion studies with rats. Also, it suggests that preexposure to sacc and 2,4,5-T abolishes the possibility to induce sacc aversion with $2,4,5-\mathrm{T}$ as the toxic agent. However, no attempt was made to separate the effects of sacc and 2,4,5-T preexposure, and the groups were exposed to different amounts of both substances prior to the last sacc$2,4,5-\mathrm{T}$ pairing. Experiment 2 was performed in order to study the effects of sacc and 2,4,5-T preexposure separately, employing better-controlled conditions.

\section{Method}

Subjects and Procedure. Twenty-eight naive male Wistar rats with a mean weight of $450 \mathrm{~g}$ were used. They were allowed an acclimatization period of 2 months. The animals were allocated to four equally sized groups $(n=7)$, matched for body weight.

With the exceptions noted below, the general procedure, housing, feeding, and environmental conditions were identical to those of Experiment 1. The experiment lasted 22 days. Two days of $20 \mathrm{~min} /$ day water-drinking intervened between injection days and 3 days elapsed between test days (see below). Initial water deprivation and adaptation to a $20 \mathrm{~min} /$ day water-drinking schedule $(1 \mathrm{~h}, 30,20,20,20,20 \mathrm{~min}, 0900$ to $0920 \mathrm{~h})$ took place on Days 1-6. On Day 7, the groups were randomly designated in the following manner (Table 2): (1) preconditioning (Precond)

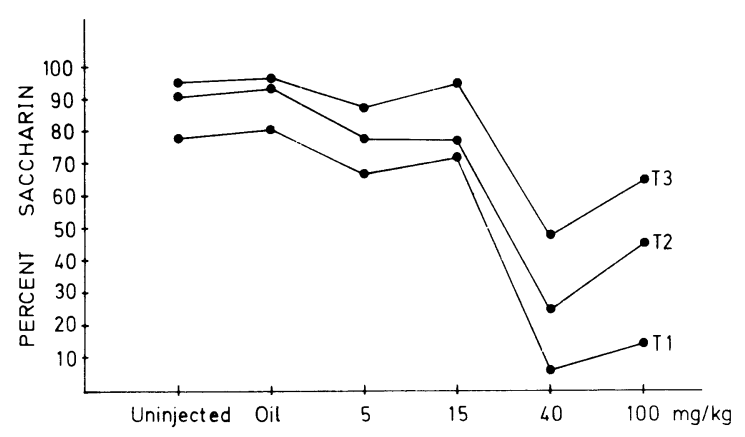

Figure 1. Mean percent saccharin preference in relation to total fluid intake on three preference tests $(T)$ for groups of rats given different doses of $2,4,5-\mathrm{T}$ paired with saccharin, and control groups. 
Table 2

Schedule of Experimental Treatments and Mean Fluid Intake (FI) in Grams in Experiment 2

\begin{tabular}{|c|c|c|c|c|c|c|c|c|}
\hline \multirow[b]{2}{*}{ Group } & \multicolumn{2}{|l|}{ Day 7} & \multicolumn{2}{|l|}{ Day 10} & \multicolumn{2}{|l|}{ Day 14} & \multirow{2}{*}{$\begin{array}{l}\text { Day } \\
18^{*}\end{array}$} & \multirow{2}{*}{$\begin{array}{l}\text { Day } \\
22 \dagger\end{array}$} \\
\hline & Treatment & FI & Treatment & FI & Treatment & FI & & \\
\hline Precond & Sacc- $2,4,5-\mathrm{T}$ & 15.1 & Sacc- $2,4,5-\mathrm{T}$ & 12.4 & Sacc- $2,4,5-\mathrm{T}$ & 12.7 & 9.3 & 10.3 \\
\hline Sacc-fam & Sacc-oil & 17.1 & Sacc-oil & 20.9 & Sacc- $2,4,5-\mathrm{T}$ & 22.6 & 54.4 & 61.3 \\
\hline 2,4,5-T-fam & Water-2, 4, 5-T & 20.3 & Water-2, 4, 5-T & 20.1 & Sacc- $2,4,5-\mathrm{T}$ & 14.9 & 64.2 & 82.9 \\
\hline Control & Water-oil & 17.6 & Water-oil & 19.3 & Sacc- $2,4,5-\mathrm{T}$ & 19.0 & 17.7 & 19.9 \\
\hline
\end{tabular}

*Percentage saccharin-preference values in relation to total fluid intake (T1).

†Percentage saccharin-preference values in relation to total fluid intake (T2).

group, given $20 \mathrm{~min}$ access to a $.1 \%$ sacc solution in two identical bottles and injected (via stomach intubation) with a single oral dose of $2,4,5-\mathrm{T}(100 \mathrm{mg} / \mathrm{kg})$ suspended in $.45 \mathrm{ml}$ corn oil; (2) saccharin-familiar (Sacc-fam) group, given sacc access and injected with a .45 -ml oil vehicle; (3) 2,4,5-T-familiar (2,4,5-T-fam) group, given access to water for $20 \mathrm{~min}$ and injected with $100 \mathrm{mg} / \mathrm{kg}$ of 2,4,5-T; and (4) control (C) group, given water for $20 \mathrm{~min}$ and injected with oil vehicle. On Day 10, the Day 7 treatments were administered anew. On Day 14, all groups were given a sacc2,4,5-T conditioning trial. Eight-hour preference tests (0900 to $1700 \mathrm{~h}$ ) were administered on Days 18 and 22.

\section{Results}

Analysis of variance was performed separately for mean daily fluid intake (1) on the water-drinking days (Days 4-6, 8-9, 11-13, and 15-17), and (2) on the preexposure/conditioning days (Days 7, 10, and 14, see Table 2). (1) The Groups by Days interaction was significant for the water-drinking days $(F=6.8$, $\mathrm{df}=9 / 72, \mathrm{p}<.01)$. Subsequent testing of pairwise differences between groups within days revealed no difference for Days 4-6 and 15-17; Precond, 2, 4, 5,-Tfam < Sacc-fam differences for Days 8-9, apparently due to the 2,4,5-T exposure of the former groups on Day 7; and a 2,4,5-T-fam < Sacc-fam difference on Days $11-13(\mathrm{p}<.01)$. (2) The Groups by Days interaction $(F=3.0, \mathrm{df}=6 / 48, \mathrm{p}<.05)$ was significant for the preexposure/conditioning days. HSD testing revealed no pairwise group differences on Day 7 (see Table 2). On Day 10, there were Precond $<$ Saccfam, 2,4,5-T-fam, $\mathrm{C}(\mathrm{p}<.05)$ differences, due to a taste-aversion effect in the former group. On Day 14, there were Precond, 2,4,5-T-fam $<$ Sacc-fam differences $(p<.01)$. The latter effect is most likely the result of the combination of an enhanced neophobia to sacc in the 2,4,5-T-fam group and a familiarization effect in the Sacc-fam group, effects tending in opposite directions.

Analysis of variance of the preference-test data revealed a significant effect of Groups $(F=8.6$, $\mathrm{df}=3 / 24, \mathrm{p}<.01$ ) (see Table 2 ) due to the following pairwise group differences: Precond $<$ Sacc-fam, 2,4,5-T-fam ( $<<.01), \mathrm{C}<2,4,5$-T-fam $(\mathrm{p}<.05)$. Apart from showing the attenuating effects of sacc and 2,4,5-T preexposure on subsequent aversion, this pattern of results indicates no differential effect of one vs. three conditioning trials.

\section{DISCUSSION}

Two experiments with the taste-aversion-inducing properties of a single oral dose of $2,4,5-\mathrm{T}$ in rats yielded evidence of a critical dose range between 15 and $40 \mathrm{mg} / \mathrm{kg}$ and of the attenuating effects of sacc as well as of 2,4,5-T preexposure on taste-aversion learning.

We obtained very little evidence of a taste-aversioninducing effect of doses of 15 and $5 \mathrm{mg} / \mathrm{kg}$ of $2,4,5-\mathrm{T}$, the only indication being that the $15-$ and $5-\mathrm{mg} / \mathrm{kg}$ groups of Experiment 1 increased their sacc preference from T1 to T3 in contrast to the control and uninjected groups. The two additional conditioning trials given to the $15-$ and $5-\mathrm{mg} / \mathrm{kg}$ groups after Preference Test 3 failed to produce any indications of a sacc aversion. Thus, as far as the possibility goes of producing taste aversion in wildlife through accidental exposure to $2,4,5-\mathrm{T}$, there seems to be a safe range at least below $15 \mathrm{mg} / \mathrm{kg}$, even though a certain amount of suppression of intake of the taste substance may be expected in this dose range. Whether or not an animal would consume as much as $40 \mathrm{mg} / \mathrm{kg}$ of $2,4,5$ - $\mathrm{T}$ under natural conditions is doubtful. It has been estimated that the maximum residue value that would result from 2,4,5-T application to an area (in the U.S.) is approximately $440 \mathrm{mg} / \mathrm{m}^{2}$ (Strange, Allred, \& Kerr, 1976). In West Germany, analyses of residues in leaves and berries between 1972 and 1974 showed values ranging between 1 and $50 \mathrm{mg} / \mathrm{kg}$ as late as 5 weeks after the exposure (Wellenstein, 1975a, $1975 \mathrm{~b}, 1975 \mathrm{c})$. In Sweden, values between 150 and $300 \mathrm{mg} / \mathrm{m}^{2}$ after herbicide spraying of an area have been estimated to occur (Giftnämnden, 1971). The residue values will, in practice, vary depending upon the mode of application, temperature, and wind conditions at the time of application (Wellenstein, 1975a). The figures reported above make it relatively unlikely that an animal could consume taste-aversioninducing amounts of 2,4,5-T via the oral route. However, when the herbicide is applied via spraying from an aeroplane, airborne doses of $150-300 \mathrm{mg} / \mathrm{m}^{3}$ could occur, at least temporarily (Giftnämnden, 1971). This would correspond to an inhalation dose of $2-10 \mathrm{mg} / \mathrm{kg} / \mathrm{h}$ for adult humans. In view of the 
most widely used method of application of 2,4,5-Tcontaining herbicides being. sprayed from an aeroplane, the respiratory route must be considered. In view of the rapid absorption of 2,4,5-T from the rat lung (Burton, Gardiner, \& Schanker, 1974), exposure via this route may be more efficient for inducing taste aversion. The critical dose range for tasteaversion learning via the respiratory route of exposure is still to be determined.

The results from the preexposure experiment (Experiment 2) may be taken to indicate that the use of phenoxyacetic acids as an herbicide entails no particular risks of producing taste-aversion learning and subsequent alterations of food preferences in wildlife. However, the results from the Sacc- and 2,4,5-T-fam groups should be compared to the mean saccpreference values of groups (not included in the present experiment) given preexposure to sacc without a subsequent conditioning trial. Such groups invariably show a preference value around $95 \%-98 \%$ (see, e.g., Sjödén \& Archer, 1977) to be compared to the values of $54 \%$ (Sacc-fam) and $64 \%(2,4,5-\mathrm{T}$ fam) of the present experiment. Thus, the experience of a sacc-2,4,5-T pairing caused an approximately $40 \%$ lower preference value in the "familiarized" groups as compared to "familiarized" nonconditioned groups.

The present conclusions must be tempered by at least two important considerations: (1) Taste aversions are a function of taste as well as poison intensity, and we do not know if plants in the field have the same salience for herbivores as sacc has for rats in the laboratory. (2) It is likely that the threshold doses of 2,4,5-T for producing taste aversion may vary between species of animals. Dogs, for instance, have been shown to have a much slower rate of elimination of 2,4,5-T than do rats (Piper, Rose, Leng, \& Gehring, 1973). Thus, the empirically determined values in the present study may not be directly generalizable to the field application of 2,4,5-T. Further studies with different species under analogous field conditions are therefore necessary.

\section{REFERENCES}

Burton, J. A., Gardiner, T. H., \& Schanker, L. S. Absorption of herbicides from the rat lung. Archives of Environmental Health, 1974, 29, 31-33.

Cappell, H., \& LeBlanc, A. E. Conditioned aversion by amphetamine: Rates of acquisition and loss of the attenuating effects of prior exposure. Psychopharmacologia (Berlin), 1975, 43, $157-162$.
Courtney, K. D., \& Moore, J. A. Teratology studies with 2,4,5trichlorophenoxyacetic acid and 2,3,7,8-tetrachlorodibenzo-pdioxin. Toxicology and Applied Pharmacology, 1971, 20, 396-403.

Domuan, M. CS preexposure in taste-aversion learning: Effects of deprivation and preexposure duration. Learning and Motivation, 1972, 3, 389-402.

Florsheim, W. H., \& Velcoff, S. M. Some effects of 2,4dichlorophenoxyacetic acid on thyroid function in the rat: Effects on iodine accumulation. Endocrinology, 1962, 71, 1-6.

Giftnämnden. [Phenoxy acids. A review of current data. Report from an expert group]. Stockholm: National Swedish Poisons and Pesticides Board, 1971.

GRote, F. W., JR., \& BRown, R. T. Conditioned taste aversions: Two-stimulus tests are more sensitive than onestimulus tests. Behavioral Research Methods \& Instrumentation, 1971, 3, 311-312.

KherA, K. S., \& McKinley, W. P. Pre- and postnatal studies on 2,4,5-trichlorophenoxyacetic acid, 2,4-dichlorophenoxyacetic acid and their derivatives in rats. Toxicology and Applied Pharmacology, 1972, 22, 14-28.

KIRK, R. E. Experimental design: Procedures for the behavioral sciences. Belmont, Calif: Brooks/Cole, 1968.

Neubert, D., \& Dillman, I. Embryotoxic effects in mice treated with 2,4,5-trichlorophenoxyacetic acid and 2,3,7,8tetrachlorodibenzo-p-dioxin. Naunyn-Schmiedeberg's Archives of Pharmacology, 1972, 272, 243-264.

Piper, W. N., Rose, J. Q., Leng, M. L., \& Gehring, P. J. The fate of 2,4,5-trichlorophenoxyacetic acid $(2,4,5-\mathrm{T})$ following oral administration to rats and dogs. Toxicology and Applied Pharmacology, 1973, 26, 339-351.

Sü̈DÉn, P. O., \& Archer, T. Conditioned taste-aversion to saccharin induced by 2,4,5-trichlorophenoxyacetic acid in albino rats. Physiology and Behavior, 1977, 19, 159-161.

Sü̈DÉN, P. O., \& SÖDERBERG, U. Sex-dependent effects of prenatal 2,4,5-trichlorophenoxyacetic acid on rats' open-field behavior. Physiology \& Behavior, 1972, 9, 357-360.

Sü̈DÉN, P. O., \& SöDERBERG, U. Long-lasting effects of prenatal 2,4,5-trichlorophenoxyacetic acid on open-field behavior in rats: Pre- and postnatal mediation. Physiological Psychology, $1975,3,175-178$.

Suödén, P. O., Archer, T., \& Söderberg, U. Effects of 2,4,5trichlorophenoxyacetic acid $(2,4,5-\mathrm{T})$ on radioiodine distribution in rats. Bulletin of Environmental Contamination and Toxicology, 1977, 17, 670-678.

Strange, J. R., Allred, P. M., \& Kerr, W. E. Teratogenic and toxicological effects of 2,4,5-trichlorophenoxyacetic acid in developing chick embryos. Bulletin of Environmental Contamination and Toxicology, 1976, 15, 682-688.

Wellenstein, G. Biologische und öko-toxikologische Probleme bei einer Flug-begiftung unserer Wälder mit Derivaten der Phenoxyessigsäure. Qualitas Plantarum-Plant Foods for Human Nutrition, 1975, 25, 1-20. (a)

Wellenstein, G. Das Rückstandsproblem nach Anwendung von Wuchsstoff-Herbiciden in der Forstwirtschaft. Allgemeine Forstund Jagd-Zeitung, 1975, 146, 63-72. (b)

Wellenstein, G. Unerlaubt hohe Pestizid-Rückstände in Waldbeeren. Umschau in Wissenschaft und Technik, 1975, 75, 510-512. (c)

(Received for publication April 20, 1978; revision accepted September 8, 1978.) 